Whodzimierz Kaczorowski, Pawel Dydyński

(Opole)

\title{
Reprezentacja Mazowsza i Podlasia wśród elektorów Wladyslawa IV Wazy w 1632 roku
}

\author{
Wähler aus Masowien und Podlachen \\ im Vergleich mit anderen Vertretungen bei der Wahl \\ von Ladislaus IV. Wasa 1632
}

1. Zasady elekcji. 2. Przebieg elekcji. 3. Ogłoszenie wyboru. 4. Spisy uczestników elekcji. 5. Charakterystyka uczestników elekcji 17 i 18 stulecia. 6. Elektorzy Władysława IV z Mazowsza i Podlasia. 7. Wnioski. Aneks: Wykaz mazowieckich i podlaskich nieutytułowanych elektorów Władyslawa IV - w podziale na województwa i ziemie.

1. Ordnung der königlichen Wahl. 2. Verlauf der Wahl. 3. Bekanntmachung der Ergebnisse. 4. Verzeichnisse der Wähler. 5. Charakteristik der Wahlteilnehmer im 17. und 18. Jh. 6. Wähler von Ladislaus IV. aus Podlachen und Masowien. 7. Schlussfolgerungen. Anhang: Verzeichnis der Wāhler aus Masowien und Podlachen ohne Amt unter Berücksichtigung der Wojewodschaften und Länder.

...że się nam królowie nie $w$ pieluchach rodzq, ale $w$ wolnych sercach $i$ glosach naszych [...], ze tych za Pany sobie bierzemy, których chcemy, nie tych mamy, których nie musimy.

Jakub Sobieski - krajczy koronny

Elekcję Whadysława Wazy na króla polskiego przeprowadzono na polu elekcyjnym między Wolą a Warszawą 8 XI 1632 r. ${ }^{1}$ Wydarzyło to się w 192.

\footnotetext{
${ }^{1}$ W trakcie prowadzonej przeze mnie kwerendy udało się ustalić 30 diariuszy sejmu elekcyjnego 1632 r. Podczas analizy ich treści okazało się jednak, że w wielu wypadkach sq to kopie podstawowych dzienników tego sejmu. W tej sytuacji, przy opracowywaniu powyższego tematu, oparłem się przede wszystkim na nastẹpujących diariuszach: Wojewódzkie Archiwum Państwowe w Gdańsku [= WAPGd.] 300, 29/112, k. 239-380v; Archiwum główne Akt Dawnych. Zbiór Branickich z Suchej $[=$ AGAD, ZBS $]$ 37/51, s. 1-162; Archiwum Glówne Akt Dawnych,
} 
dniu bezkrólewia po śmierci Zygmunta $\mathrm{III}^{2}$. Jednak, nim przystąpiono do obioru nowego króla, senatorowie i posłowie zebrani na sejmie elekcyjnym trwającym 40 dni, musieli 8 listopada podjąć istotną decyzję, czy odbyć elekcje $w$ tym dniu zgodnie $z$ uchwałą sejmu konwokacyjnego, czy też przesunać ją na termin późniejszy. Nie zdążono bowiem na czas przedyskutować wszystkich punktów egzorbitancji i paktów konwentów przygotowywanych do akceptacji nowemu królowi. ${ }^{3}$ W tej sytuacji prymas Jan Wężyk oświadczyl, że król powinien być wybrany 8 listopada, a po przeprowadzeniu elekcji oficjalna nominacja będzie przesunięta o kilka $\mathrm{dni}^{4}$. Osiągnięta $\mathrm{w}$ ten sposób zwłoka pozwoliłaby przedyskutować pozostake punkty egzorbitancji i paktów konwentów. Nie wszyscy uczestnicy elekcji godzili się jednak na takie rozwiązanie. Niektórzy - jak Marek Radoszewski, kasztelan wieluński - nalegali, aby przesunąć elekcję na koniec obrad ${ }^{5}$. Rzecz ciekawa, iż takie propozycje przedyskutowania egzorbitancji wychodzily nie tylko $\mathrm{z}$ kręgów szlacheckich, lecz również z senatorskich.

Poddawano dyskusji sposób przeprowadzenia elekcji. Dyskutowano przede wszystkim nad systemem oddawania głosów na elekta. Chodziło o to, czy wszyscy uprawnieni do głosowania będą oddawać głosy viritim w jednym wspólnie utworzonym centralnie kole, czy też w kolach swoich województw $\mathrm{z}$ przedstawieniem wyników głosowania przez wybranych przedstawicieli, prawdopodobnie najwyższych stanowiskiem. Informacje źródłowe o sposobie wyboru nowego króla nie są precyzyjne, lecz $\mathrm{z}$ zestawienia różnych relacji wynika, że ostatecznie ustalono, iż nie będzie koła generalnego, powstaną natomiast kola wojewódzkie, zachowując zasadę viritim. Przedstawiciele kól wojewódzkich byli obowiązani złożyć prymasowi wspomniane oświadczenia ${ }^{6}$.

Archiwum Publiczne Potockich [= AGAD, APP] 32, s. 1-215; Biblioteka Polskiej Akademii Nauk w Krakowie [= BPANKr.] 1636, s. 1-101; Biblioteka Muzem im. ks. Czartoryskich w Krakowie [= BCz.] 124, s. 735-837; Biblioteka Kórnicka Polskiej Akademii Nauk [= BK] 1317 , s. $131-169$.

${ }^{2}$ W. K aczorowski, Choroba i prawdopodobna przyczyna zgonu Zygmunta III Wazy, Archiwum Historii Medycyny 1983, t. 45, z. 1-4, s. 45-54.

${ }^{3}$ Deputacje do paktów konwentów wyznaczono 2 listopada, jednak do dnia obioru króla nie ukończyła ona swej pracy (WAPGd. $300,29 / 112$, k. 308-308v; BCz. 124, s. 820; W. Sobo ci ński, Akta z czasów bezkrólewia 1632 roku, Poznań 1949, s. 26).

4 Wyborowi króla towarzyszyło wiele innych aktów, bez których nie był on zupełny i ważny: nominacja przez prymasa, publikacja przez marszałków, wręczenie dyplomu elekcyjnego (BCz. 124, s. 820; W. Sob ocińs ki, $A k t a \ldots$, s. 26 ).

5 Ibidem, s. 821.

- WAPGd. 300, 29/112, k. 308v. 
Okazało się jednak, że nie były to ściśle koła wojewódzkie, gdyż na przykład ziemia wieluńska utworzyla własne koło, nie głosując w ramach województwa sieradzkiego ${ }^{7}$. Również przedstawiciele powiatu pińskiego nie głosowali $w$ kole województwa brzesko-litewskiego ${ }^{8}$. $\mathrm{Z}$ relacji autora diariusza gdańskiego wynika, że deklaracje składane przed prymasem również nie przebiegały jednolicie'. Senatorowie ziem pruskich i zapewne innych głosowali viritim $\mathrm{w}$ swoim kole $\mathrm{i} \mathrm{w}$ senacie, to znaczy dwukrotnie ${ }^{10}$. Zdarzały się i takie sytuacje, jak w przypadku Melchiora Weihera - wojewody chełmińskiego, który kwestionował konieczność osobistego wypowiadania się, argumentując to faktem oświadczenia złożonego $w$ imieniu wszystkich posłów i senatorów pruskich przez Jakuba Zadzika - biskupa chelmińskiego $^{11}$. Autor jednego z diariuszy tak zarejestrował przebieg elekcji w kołach:

Poczquszy od Pana wojewody onego województwa aż do statecznej osoby, którzy się do onegoż województwa nalezeć rozumial, suffragia swoje dawali na króla nowego, i tam zarazem wszystkich, a wszystkich z każdego województwa nomine et cognomine spisowali ${ }^{12}$.

W glosowaniu brali udzial również przedstawiciele miast: Gdańska, Krakowa, Lwowa, Poznania, Torunia i Wilna, którzy oddawali głosy na nowego króla za pośrednictwem swoich burmistrzów ${ }^{13}$. W Gdańsku glosowal burmistrz Konstanty Ferber, w Toruniu - burmistrz Jakub Simon. Złożyli oni wobec prymasa odpowiednie oświadczenie $w$ imieniu całej delegacji składającej się $\mathrm{z}$ posłów miejskich tych miast ${ }^{14}$.

Przeprowadzona w ten sposób elekcja, niejako dwustopniowa, odbyła się bardzo sprawnie - jak odnotowal Albrycht Stanisław Radziwill - w ciagu jednej godziny dokonala sie elekcja ${ }^{15}$. Jednomyślność wśród szlachty była tak powszechna, że wszyscy zgodnie oddali głosy na królewicza Władysława, jako nowego króla Polski, przy ogólnej aklamacji: Wiwat! Niech żyje król

\footnotetext{
${ }^{7}$ Ibidem, k. 310; BCz. 124, s. 820-821; AGAD, ZBS 37/51, s. 128-129.

BCz. 124, s. 822-823.

${ }^{9}$ WAPGd. $300,29 / 112$, k. 309v-310v.

${ }^{10}$ Ibidem, k. 309.

11 Ibidem, k. $310 \mathrm{v}$.

12 AGAD, ZBS 37/51, s. 129.

13 Ibidem, s. 129; WAPGd. 300, 29/112, k. 310v.

14 WAPGd. 300, 29/112, k. 310.

15 A. S. R a dzi wiłt, Pamiętnik o dziejach $w$ Polsce, przeł. i oprac. A. Przyboś, R. Żelewski, t. 1: 1632-1636, Warszawa 1980, s. 208.
} 
Władysław! ${ }^{16}$ Elekcja miała tak sprawny przebieg również dlatego, że przyjęty system deklaracji przez przedstawicieli poszczególnych województw, ziem i powiatów, skracal znacznie całą procedurę oddawania głosów, nie przekreślając zasady viritim. System ten nie był przez nikogo kwestionowany. Dokonany podział na koła wojewódzkie, ziemskie i powiatowe znacznie upraszczal system wotowania.

Po przygotowaniu paktów konwentów, tj. 12 listopada, zaprzysiąc je musieli posłowie Władysława, aby następnie J. Wężyk mógł dokonać jego nominacji na króla polskiego. Prymas - zgodnie ze wspomnianą deklaracją - zamierzał oglosić wybór nowego króla dopiero 13 listopada, po pięciodniowej zwłoce. Odłożenie nominacji nie było z pewnością przyjemne dla elekta, gdyż moglo świadczyć o pewnym braku zaufania przed objęciem rządów w państwie. Posłowie Władysława (Aleksander Ludwik Radziwill - wojewoda brzesko-litewski, Jerzy Ossoliński - podskarbi nadworny koronny, Kazimierz Leon Sapieha - pisarz litewski, Janusz Wiśniowiecki - starosta krzemieniecki, Zygmunt Kazanowski - starosta kokenhauski, Mikołaj Koryciński - starosta ojcowski; Henryk Firlej - biskup przemyski, nieobecny $\mathrm{z}$ powodu nagłego zasłabnięcia) 13 listopada przybyli na pole elekcyjne do koła generalnego pod gołym niebem ${ }^{17}$. $Z$ oświadczenia prymasa wynika, że po złożeniu relacji przez posłów i wyrażeniu zgody przez Władysława na zatwierdzenie paktów konwentów można będzie przystąpić do właściwego aktu nominacji. Nominację, zgodnie ze zwyczajem, poprzedzała przysięga złożona przez posłów w imieniu elekta, który osobiście - po dokonanym akcie elekcyjnym - ponawiał ją w obliczu Boga i narodu w kościele św. Jana w Warszawie. Przysięgę, zwyczajem przodków, składali posłowie w środku koła generalnego ${ }^{18}$. Ze względu na utrzymujące się opady deszczu i rozmoczoną ziemię, w miejscu składania przysięgi rozłożono kobierzec biskupa krakowskiego, nie dysponując innym zabezpieczeniem ${ }^{19}$. Posłowie, klęcząc pod gołym niebem, złożyli publicznie przysięgę odczytaną przez J. Zadzika - kanclerza wielkiego koronnego i biskupa chełmińskiego, w asyście Albrychta Stanisława Radziwiłła - kanclerza wielkiego litewskiego, Tomasza Zamoyskiego - podkanclerzego koronnego, Pawła Stefana Sapiehy - podkanclerzego litewskiego, oraz Jana

${ }^{16}$ Obioru Władysława IV dokonano za zgodą wszystkich uprawnionych do udziału w elekcji i obecnych na polu elekcyjnym (WAPGd. 300, 29/112, k. 310v; BCz. 124, k. 824; AGAD, ZBS $37 / 51$, s. $120-130$.

17 WAPGd. $300,29 / 112$, k. 321.

${ }_{18}$ A. S. R a d ziwiłł, Pamietnik..., t. 1, s. 236.

$19 \mathrm{BCz} .124$, s. 833. 
Wężyka trzymającego krzyż, a także pozostałych obecnych senatorów i dygnitarzy Rzeczypospolitej ${ }^{20}$. Po złożonej przysiędze J. Ossoliński zwrócil się do zebranych senatorów, postów ziemskich i wszystkich przybyłych na tę uroczystość, $\mathrm{z}$ podziękowaniem $\mathrm{w}$ imieniu Władysława za okazany szacunek i przychylność względem jego osoby, oświadczając, że król Władysław, to co obecnie zostało zaprzysiężone, nie tylko zaślubi, lecz w samej istocie popiera i pochwala ${ }^{21}$. Świadkami nominacji byli królewiczowie: Jan Kazimierz, Karol Ferdynand, Jan Albert, Aleksander Karol. Prymas, przystępując do aktu nominacji, wyglosił mowę kończącą się następującymi słowami:

...tedy z urzędu mego, powierzonego mi przez Rzeczpospolita, nominuje Wadyslawa Zygmunta III, wybranego wolnymi i zgodnymi glosami tej Rzeczypospolitej, na króla Polski $i^{22}$.

Za pośrednictwem czterech marszalków wysłanych do Zamku Królewskiego, arcybiskup powiadomil Wladyslawa o mianowaniu go na króla polskiego. Akt publikacji odczytał królowi Władysławowi - w imieniu pozostałych marszałków - Lukasz Opaliński, marszałek wielki koronny ${ }^{23}$.

Po oznajmieniu przezeń o elekcji króla Władysława, królewicze dziękowali Rzeczypospolitej za okazaną ich bratu przychylność, a Jan Kazimierz - najstarszy $z$ rodzeństwa, serdecznie wszystkim zebranym podziękował za wybór brata na tron królewski ${ }^{24}$. $\mathrm{Z}$ inicjatywy J. Wężyka zebrani na polu elekcyjnym zaintonowali: Te Deum laudamus ${ }^{25}$. Jak odnotowal w swoim pamiętniku A. S. Radziwiłł, dziwne, że $w$ takim wielkim zgromadzeniu w najwyższym porzqdku wszystko sie dokonalo $k u$ wielkiej radości $i$ nie bez lez wzruszenia. Co gdy sie skończylo, wszyscy wzajemnie sie ściskali ${ }^{26}$. Po odśpiewaniu pieśni, konnica, jak i kilkadziesiąt chorągwi piechoty oddały salut ${ }^{27}$. A. S. Radziwilł tak odnotował ten moment: Zdalo sie, że rozbrzmiewaja $i$ grzmiq ziemia $i$ niebo ${ }^{28}$. Wiwaty trwały ponad dwie godziny, po czym uczestnicy tej doniosłej i niepowtarzalnej uroczystości przy dźwiękach bębnów, trąb, fletów i innych instrumentów ruszyli do miasta, kończąc pochód dopiero późnym wieczorem ${ }^{29}$.

\footnotetext{
${ }^{20}$ WAPGd. 300, 29/112, k. 321; A. S. R adziwi11, Pamiętnik..., t. 1, s. 236.

21 WAPGd. 300, 29/112, k. 322.

${ }_{22}$ A. S. R adzi will, Pamietnik..., t. 1, s. 237.

${ }^{23}$ WAPGd. 300, 29/112, k. 322v.

${ }^{24}$ Ibidem, k. $322 \mathrm{v}$.

25 Ibidem, k. 323.

${ }^{26}$ A. S. R adziwiłł, Pamietnik..., t. 1, s. 238.

27 WAPGd. $300,29 / 112$, k. 323; BCz. 124, k. 833.

${ }^{28}$ A. S. R adziwiłł, Pamietnik..., t. 1, s. 833.

${ }^{29}$ WAPGd. 300, 29/112, k. 323v.
} 
Formalnie Władysław został królem 14 XI 1632 r. - w tydzień później od daty wyznaczonej na sejmie konwokacyjnym, gdy po odprawionym przez prymasa J. Wężyka nabożeństwie w kościele św. Jana nastąpiła uroczysta przysięga. Król podszedł do ołtarza i przysiągl na Ewangelię, że pakta konwenta, uprzednio zaprzysiężone w jego imieniu przez posłów, będą przez niego przestrzegane, jak również ponownie zaprzysiężone po koronacji ${ }^{30}$. $\mathrm{Z}$ chwilą tą skończyło się sprawowanie władzy przez prymasa J. Wężyka jako interreksa, trwające $198 \mathrm{dni}$.

W trakcie oddawania głosów na Władysława spisywano je, by przygotować ogólny wykaz elektorów. W rękopisie wykaz sporządzono bezpośrednio po elekcji, ale drukiem wydano go dopiero w 1633 r. w Krakowie ${ }^{31}$. Znajduje się on w Zakładzie Narodowym im. Ossolińskich - Biblioteka PAN we Wrocławiu aż w pięciu egzemplarzach ${ }^{32}$, kopie zaś w wielu diariuszach sejmu elekcyjnego ${ }^{33}$. Nie natrafiliśmy, niestety, na oryginał tego aktu.

Elektorami Władysława IV, Michała Korybuta Wiśniowieckiego i Stanislawa Leszczyńskiego zainteresował się na początku XX w. J. Dunin-Borkowski, odnajdując ich nazwiska, a następnie układając je alfabetycznie. W takim układzie wykaz elektorów został przygotowany do druku wspólnie z M. Dunin-Wąsowiczem ${ }^{34}$. Wydanie to jest jednak mało praktyczne, gdyż elektorów $\mathrm{z}$ trzech kolejnych elekcji przedstawiono łącznie, nie zachowując chronologii, co zmusza do wyszukiwania nazwisk i tytułów wyborców poszczególnych wladców. Poza podsumowaniem głosów z kolejnych elekcji, nie poddano też - co istotne - analizie zawartych w tym wykazie danych personalnych.

${ }^{30}$ Ibidem, k. 323v; W. B e nd za, Wladyslaw IV a kościól prawoslawny (1632-1648), Rocznik Teologiczny Chrześcijańskiej Akademii Teologicznej 1978, R. XX, z. 2, s. 53; W. Cz a plińs k i, Wladyslaw IV $i$ jego czasy, Warszawa 1972, s. 116-117.

${ }^{31}$ Procedura wyboru króla polegała na stwierdzeniu dla każdej jednostki sejmikowej (województwa, ziemi) ustnej zgody wszystkich, a niezależnie od tego zbierano podpisy (suffragia). W S ob oc iń sk i, Akta..., s. 26; E. T rille r, Bibliografia konstytucji sejmowych XVII wieku w Polsce $w$ swietle badań archiwalnych, Wroctaw 1965, s. 55-56.

${ }^{32}$ B.Ossol. XVII 18 203; XVII 18 210; XVII 18 028; XVII 18 032; XVII 18597.

${ }^{33}$ BCz. MN 158, k. 200-200v; BCz. 363, k. 281-301; BJ 19/52, k. 257-279.

${ }^{34}$ Elektorowie królów Wladyslawa IV, Michala Korybuta, Stanislawa Leszczyńskiego i spis stronników Augusta III, t. I: 1908/9, zestawili w porządku abecadłowym: J. Du n in-B ork ow ski i M. Dunin-W ą s owicz, Rocznik Towarzystwa Heraldycznego, [Lwów] 1910. 
Statystyczne wyliczenia pozwalają oszacować liczbę głosów oddanych na niektórych polskich władców elekcyjnych. Zagadnienie to ilustruje tabela 1, ułożona według liczby głosów oddanych na poszczególnych elekcjach ${ }^{35}$.

Tabela 1: Liczba glosów oddanych na niektórych polskich królów elekcyjnych

\begin{tabular}{|c|l|c|}
\hline Lp. & \multicolumn{1}{|c|}{ Król } & Liczba oddanych głosów \\
\hline 1 & August II Mocny & 13641 \\
2 & Stanisław Leszczyński & 11697 \\
3 & Michał Korybut Wiśniowiecki & 11271 \\
4 & Stanisław August Poniatowski & 5320 \\
5 & Jan Kazimierz & 4352 \\
6 & Władysław IV & 3543 \\
7 & Jan III Sobieski & 3450 \\
8 & August III & 906 \\
\hline \multicolumn{2}{|l|}{ Razem } & 54180 \\
\hline
\end{tabular}

Największą - jak widać - liczbę elektorów mial August II, Stanisław Leszczyński i Michał Korybut Wiśniowiecki. Władysław IV uzyskał mniej głosów od Jana Kazimierza, ale więcej od Jana III Sobieskiego i Augusta III. Ogółem na ośmiu władców elekcyjnych oddano 54180 głosów, co średnio stanowi 6772 głosy. Z obliczeń wynika, że elektorów Władysława IV było w przybliżeniu o połowę mniej od podanej przeciętnej.

W połowie lat osiemdziesiątych XX w. dokładną analizę elektorów Władysława IV przeprowadzil Włodzimierz Kaczorowski, wyodrębniając reprezentację Wielkopolski, Małopolski, Wielkiego Księstwa Litewskiego i Prus Królewskich ${ }^{36}$. Poza zakresem jego zainteresowań pozostała reprezentacja Mazowsza i Podlasia.

Przeprowadzona przez nas kontrola obliczeń zestawionych przez J. Dunin-Wąsowicza potwierdzila, że na Władysława IV oddano faktycznie 3543 głosy. Koronę reprezentowało 2847 elektorów (tj. 80,3\%), Litwę - 696 $(19,7 \%)$. Na czterech Koroniarzy przypadał więc jeden Litwin. Dalsza analiza statystyczna ujawniła, że spośród 3543 elektorów $618(17,4 \%)$ było utytułowanych, natomiast $2925(82,6 \%)$ nie posiadało żadnego tytułu. Dla Korony

35 Ibidem, s. 6-7.

${ }^{36}$ W. K a c z or ow s ki, Wielkopolanie wśród elektorów Wladyslawa IV, CPH 1984, t. 36, z. 2, s. 179-194; t tenż e, Malopolanie wśród elektorów Wladyslawa $I V$, SH 1984, t. 27, z. 4, s. 571-592; t e nże, Reprezentacja Prus Królewskich wśród elektorów Wladyslawa $I V$ w 1632 roku, Zapiski Historyczne 1985 , t. 50, z. 2, s. 15-25; ten że, Litwini wśród elektorów Wladystawa IV, Rocznik Białostocki 1991, nr 17, s. 191-211. 
wskaźniki te ksztaltowały się odpowiednio $475(16,7 \%)$ : $2372(82,3 \%)$, a dla Litwy $143(20,5 \%)$ : $553(79,5 \%)$. Ogólnie na czterech elektorów nieutytulowanych przypadal jeden utytulowany, przy czym dla Korony wskaźniki kształtowały się jak 5:1, a dla Litwy jak $4: 1$. Zagadnienie to ilustruje tabela 2 .

Tabela 2: Elektorzy Władysława IV w podziale na Koroniarzy i Litwinów

\begin{tabular}{|l|c|c|c|c|c|c|}
\hline \multirow{2}{*}{ Rzeczpospolita } & \multicolumn{4}{|c|}{ Elektorzy } & \multicolumn{3}{c|}{ Razem } \\
\cline { 2 - 7 } & \multicolumn{2}{|c|}{$\mathrm{z}$ tytułami } & \multicolumn{2}{c|}{ bez tytułów } & \multicolumn{1}{c|}{} \\
\cline { 2 - 7 } & $1 . \mathrm{b}$. & $\%$ & $1 . \mathrm{b}$. & $\%$ & $1 . \mathrm{b}$. & $\%$ \\
\hline Korona & 475 & 16,7 & 2372 & 83,3 & 2847 & 100,0 \\
Litwa & 143 & 20,5 & 553 & 79,5 & 696 & 100,0 \\
\hline Razem & 618 & 17,4 & 2925 & 82,6 & 3543 & 100,0 \\
\hline
\end{tabular}

Liczby te nie są jednak precyzyjne, ostatnia bowiem strona wykazu elektorów Władysława IV zawiera adnotacje wskazującą, że wymienieni wyborcy składali swe podpisy nie tylko we własnym imieniu, lecz również tych, którzy bezpośrednio po nominacji króla opuścili pole elekcyjne ${ }^{37}$. W takich warunkach nietrudno o pomyłkę i można przyjąć, że w rzeczywistości liczba wyborców Władysława IV była zapewne wyższa, i to przypuszczalnie o kilkaset osób.

Celem artykułu jest wydzielenie reprezentacji Mazowsza i Podlasia uczestniczących w elekcji Władysława IV, według zachowanego wykazu elektorów. Przeprowadzenie takiej analizy jest próbą oceny aktywności politycznej Mazowszan i Podlasian na tle przedstawicieli pozostałych województw i ziem koronnych i litewskich. Pozwoli też zrewidować stereotyp o masowym udziale Mazowszan i Podlasian w wyborze Władysława IV.

Obliczeniami statystycznymi objęliśmy Mazowsze i Podlasie. Terytorium Mazowsza w epoce Wazów podzielone było na trzy województwa: mazowieckie, płockie i rawskie. Mazowieckie tworzyło dziesięć ziem (czerska, warszawska, wyszogrodzka, zakroczymska, różańska, nurska, liwska, wiska, ciechanowska, łomżyńska). Rawskie składało się z trzech ziem: gostyńskiej, rawskiej i sochaczewskiej, a płockie tworzyły dwie ziemie: zawkrzeńska i płocka ${ }^{38}$.

\footnotetext{
${ }^{37}$ Nie tylko naszym, ale $i$ tych, których wielka liczba zaraz po szcześliwej nominacyjej nie mogqc dla prętkiego odjazdu na podpisy swe czekać, rozjechala się $i$ inszych $w$ domach pozostalej braciej naszej imieniem modo quo supra podpisaliśmy sie (cyt. za: Elektorowie królów..., s. 6).

${ }^{38}$ J. Choińska-Mika, Sejmiki mazowieckie w dobie Wazów, Warszawa 1998, s. 9.
} 
Natomiast województwo podlaskie podczas sejmu lubelskiego w $1569 \mathrm{r}$. zostało inkorporowane do Korony, skladało się z trzech ziem: drohickiej, mielnickiej i bielskiej. W każdej ziemi funkcjonowały odrębne sejmiki obradujące $w$ ich stolicach. Sejmikiem generalnym właściwym dla województwa podlaskiego był obradujący w Warszawie ,general" mazowiecki ${ }^{39}$. Potwierdza to Instructuarium kancelarii koronnej: ...sejmik generalny [...] tak Podlasia, jak Mazowsza odbywa się $w$ Warszawie ${ }^{40}$. Wyżej wymieniona instrukcja kancelarii koronnej potwierdza fakt przynależności Mazowsza i Podlasia do prowincji wielkopolskiej ${ }^{41}$.

Mazowsze i Podlasie posiadaly na ogólną liczbę 3543 suffragatorów Władysława IV, 1132 swoich przedstawicieli, co stanowiło 32,0\% ogółu wyborców, 48,4\% stanowili elektorzy z pozostałych województw koronnych, a $19,6 \% \mathrm{z}$ województw litewskich. Tak więc na trzech elektorów $\mathrm{z}$ pozostałych województw koronnych i litewskich przypadal jeden wyborca z Mazowsza i Podlasia. $\mathrm{Z}$ powyższego wyliczenia wynika, że Mazowszanie i Podlasianie stanowili większą grupę wyborców niż Litwini, Małopolanie i Wielkopolanie. Natomiast biorąc pod uwagę ogólną liczbę Koroniarzy wśród elektorów Władysława IV, Mazowszanie i Podlasianie stanowili tu mniejszą reprezentację. W przybliżeniu na 2,4 elektorów $\mathrm{z}$ pozostałych województw koronnych przypadał jeden reprezentant z Mazowsza i Podlasia. Reprezentacja Mazowsza bez Podlasia liczyła 984 wyborców, co stanowiło $27,77 \%$ ogólu wyborców ${ }^{42}$.

Dokładniejsza analiza statystyczna ujawnila, że wśród 3543 elektorów - $618(17,4 \%)$ było utytułowanych, z kolei aż $2925(82,6 \%)$ nie posiadało żadnego tytułu. Dla Mazowsza i Podlasia wskaźniki te kształtowały się następująco: $199(17,6 \%)$ posiadało tytuł, a $933(82,4 \%)$ elektorów było bez żadnego tytułu. W układzie globalnym Mazowszanie i Podlasianie posiadali $32,2 \%$ elektorów utytułowanych, pozostałe województwa koronne $45,7 \%$, a województwa litewskie $23,1 \%$. Jak wynika z powyższej analizy, na trzech elektorów utytułowanych $z$ pozostałych województw koronnych i litewskich przypadal jeden elektor reprezentujący Mazowsze i Podlasie. W grupie wyborców utytułowanych z Korony, Mazowszanie i Podlasianie stanowili $41,9 \%$, a elektorzy $\mathrm{z}$ pozostałych województw koronnych $58,1 \%$, czyli

\footnotetext{
${ }^{39}$ Por. J. G i er o wski, Sejmik Generalny Księstwa Mazowieckiego na tle ustroju sejmikowego Mazowsza, Wrocław 1948; Urzędnicy podlascy XVI-XVIII wieku. Spisy, oprac. E. Dubas-Urwanowicz, W. Jarmolik, M. Kulecki, J. Urwanowicz, Kórnik 1994, s. 15.

${ }^{40}$ Kancelaria koronna a sejm walny. Instructuarium, oprac. i przett., wstępem opatrzył W. Krawczuk, Warszawa 1995, s. 80.

${ }^{41}$ Ibidem, S. 102.

42 J. D zi ęg i elewski (Sejmy elekcyjne, elektorzy, elekcje 1573-1674, Pułtusk 2003, s. 74) podał, że reprezentacja Mazowszan liczyła 982 wyborców Władysława IV, co stanowiło $27,72 \%$ ogólu suffragatorów.
} 
w przybliżeniu na dwóch elektorów przypadal jeden reprezentant z Mazowsza i Podlasia.

Spośród wszystkich województw i ziem mazowieckich oraz województwa podlaskiego najliczniej zaprezentowały się województwa: podlaskie (148 wyborców), płockie (115 wyborców) i ziemia ciechanowska (115 wyborców). Najmniej liczną reprezentację miały ziemie: wyszogrodzka (32 wyborców) i sochaczewska (34 wyborców). Liczebność mazowieckiej i podlaskiej reprezentacji z podziałem na województwa i ziemie ilustruje tabela 3.

Tabela 3: Mazowieccy i podlascy elektorzy Władysława IV Wazy w podziale na województwa i ziemie

\begin{tabular}{|c|c|c|c|c|c|c|}
\hline \multirow{3}{*}{$\begin{array}{l}\text { Województwo, } \\
\text { ziemia }\end{array}$} & \multicolumn{4}{|c|}{ Elektorzy } & \multirow{2}{*}{\multicolumn{2}{|c|}{ Razem }} \\
\hline & \multicolumn{2}{|c|}{ z tytulami } & \multicolumn{2}{|c|}{ bez tytułów } & & \\
\hline & l.b. & $\%$ & 1.b. & $\%$ & 1.b. & $\%$ \\
\hline $\begin{array}{l}\text { Woj. mazowieckie } \\
\text { z. czerska }\end{array}$ & 19 & 23,5 & 62 & 76,5 & 81 & 100,0 \\
\hline $\begin{array}{l}\text { Woj. mazowieckie } \\
\text { z. warszawska }\end{array}$ & 14 & 17,7 & 65 & 82,3 & 79 & 100,0 \\
\hline $\begin{array}{l}\text { Woj. mazowieckie } \\
\text { z. wiska }\end{array}$ & 10 & 14,7 & 58 & 85,3 & 68 & 100,0 \\
\hline $\begin{array}{l}\text { Woj. mazowieckie } \\
\text { z. wyszogrodzka }\end{array}$ & 11 & 34,4 & 21 & 65,6 & 32 & 100,0 \\
\hline $\begin{array}{l}\text { Woj. mazowieckie } \\
\text { z. zakroczymska }\end{array}$ & 12 & 29,3 & 29 & 71,7 & 41 & 100,0 \\
\hline $\begin{array}{l}\text { Woj. mazowieckie } \\
\text { z. ciechanowska }\end{array}$ & 11 & 9,6 & 104 & 90,4 & 115 & 100,0 \\
\hline $\begin{array}{l}\text { Woj. mazowieckie } \\
\text { z. łomżyńska }\end{array}$ & 13 & 25,0 & 39 & 75,0 & 52 & 100,0 \\
\hline $\begin{array}{l}\text { Woj. mazowieckie } \\
\text { z. różańska }\end{array}$ & 4 & 6,2 & 61 & 93,8 & 65 & 100,0 \\
\hline $\begin{array}{l}\text { Woj. mazowieckie } \\
\text { z. liwska }\end{array}$ & 10 & 14,5 & 59 & 85,5 & 69 & 100,0 \\
\hline $\begin{array}{l}\text { Woj. mazowieckie } \\
\text { z. nurska }\end{array}$ & 16 & 17,6 & 75 & 82,4 & 91 & 100,0 \\
\hline Woj. płockie & 18 & 15,7 & 97 & 84,3 & 115 & 100,0 \\
\hline Woj. podlaskie & 24 & 16,2 & 124 & 83,8 & 148 & 100,0 \\
\hline $\begin{array}{l}\text { Woj. rawskie } \\
\text { z. rawska }\end{array}$ & 15 & 19,0 & 64 & 81,0 & 79 & 100,0 \\
\hline $\begin{array}{l}\text { Woj. rawskie } \\
\text { z. sochaczewska }\end{array}$ & 11 & 32,4 & 23 & 67,6 & 34 & 100,0 \\
\hline $\begin{array}{l}\text { Woj. rawskie } \\
\text { z. gostyńska }\end{array}$ & 11 & 17,5 & 52 & 82,5 & 63 & 100,0 \\
\hline Razem & 199 & 17,6 & 933 & 82,4 & 1132 & 100,0 \\
\hline
\end{tabular}

Objaśnienie: Reprezentacje województwa płockiego i podlaskiego glosowaly w ramach swoich województw bez podziału na ziemie. 
Wśród elektorów reprezentujących Mazowsze i Podlasie było 12 senatorów, przy czym w pracach sejmu elekcyjnego uczestniczyło 13. W suffragii Władysława IV nie znalazł się Franciszek Wessel - kasztelan ciechanowski. Możemy przypuszczać, że wyjechał on $\mathrm{z}$ Warszawy przed zakończeniem sejmu elekcyjnego. Wśród wyborców nowego króla byli następujący mazowieccy i podlascy senatorowie: Stanisław Lubieński - biskup płocki, Jan Stanisław Karnkowski - wojewoda płocki, Stanisław Warszycki - wojewoda mazowiecki, Filip Wołucki - wojewoda rawski, Walenty Zieliński - kasztelan większy płocki, Mikołaj Giżycki - kasztelan większy czerski, Stanisław Niemira - kasztelan większy podlaski, Walenty Plichta - kasztelan większy rawski, Franciszek Filip Lipski - kasztelan mniejszy sochaczewski, Stanisław Wilkanowski - kasztelan mniejszy wyszogrodzki, Jan Brochowski - kasztelan mniejszy zakroczymski, Piotr Żabicki - kasztelan mniejszy liwski.

Należy zaznaczyć, że pod aktem elekcyjnym Władysława IV podpisało się 79 senatorów ${ }^{43}$, co stanowiło $53,7 \%$ ówczesnego składu senatu. Z kolei wśród 3543 elektorów senatorowie stanowili $2,2 \%$, a w grupie 618 wyborców utytułowanych $12,7 \%$. Z czego 12 senatorów reprezentowało Mazowsze i Podlasie, co stanowiło 8,2\% wyborców Władysława reprezentujących 147 osobowy senat ${ }^{44}$. Senatorowie $\mathrm{z}$ Mazowsza i Podlasia stanowili tylko $0,3 \%$ ogółu wyborców nowego króla, w grupie 618 elektorów utytułowanych stanowili $1,9 \%$, z kolei wśród utytułowanych elektorów z Korony (475) - 2,5\%. Spośród utytułowanych elektorów reprezentujących Mazowsze i Podlasie (199), senatorowie stanowili 6,0\%. W elekcji królewicza Władysława Wazy uczestniczył jeden biskup, co stanowiło $8,3 \%$ w stosunku do pozostałych senatorów reprezentujących Mazowsze i Podlasie. Wśród wyborców było trzech wojewodów, co stanowiło $25,0 \%$, czterech kasztelanów większych, co stanowiło $33,3 \%$ senatorów mazowieckich i podlaskich, czterech kasztelanów mniejszych, co stanowiło 33,3\% senatorów z Mazowsza i Podlasia. Trzynastu senatorów (76,5\%) reprezentujących Mazowsze i Podlasie wzięło udział w pracach sejmu elekcyjnego, a 12 złożyło swe podpisy pod aktem elekcji nowego władcy, co stanowiło 70,6\% ustawowego składu Mazowszan i Podlasian $w$ senacie $^{45}$.

${ }^{43}$ Wlaściwie senatorów podpisujących się za wyborem nowego króla było 78 , gdyż Jakub Zadzik podpisał się podwójnie - raz jako biskup chełmiński i ponownie jako kanclerz wielki koronny.

${ }^{44}$ Skład senatu w owym czasie złożony był ze 147 osób, w tym 16 biskupów, 38 wojewodów, 38 kasztelanów większych, 49 kasztelanów mniejszych i 10 ministrów. Dzielili się oni także na 113 Koroniarzy, 27 Litwinów i 7 Inflantczyków.

${ }^{45}$ Pod aktem elekcyjnym podpisało się 12 senatorów z Mazowsza i Podlasia, wśród suffragatorów zabrakło kasztelana ciechanowskiego, który uczestniczył w pracach sejmu, lecz nie złożył swego podpisu pod aktem elekcyjnym. Ustawowy sklad Mazowszan i Podlasian w senacie liczył 17 osób. Na elekcję nie stawiła się grupa 4 senatorów reprezentujących Mazowsze i Podlasie. Byli wśród nich: wojewoda podlaski, kasztelan mniejszy warszawski, gostyński i wiski. 


\section{7}

Analizując frekwencję senatorów z Mazowsza i Podlasia wśród wyborców Władysława IV, wyróżniamy jednego biskupa, co stanowiło $100 \%$ ustawowego składu senatu dla Mazowsza i Podlasia, trzech wojewodów - $75 \%$, czterech kasztelanów większych, co stanowiło $100 \%$, czterech kasztelanów mniejszych, co stanowiło $50 \%$ ustawowego składu Mazowszan i Podlasian w senacie.

Z powyższego wywodu wynika że największą frekwencją wśród senatorów mazowieckich i podlaskich (elektorów Władysława IV) wykazali się biskupi i kasztelanowie więksi, po nich wojewodowie, natomiast najmniej liczni pod względem frekwencji byli kasztelanowie mniejsi. Powyższą analizę senatorów mazowieckich i podlaskich przedstawia tabela 4 .

Tabela 4: Skład i frekwencja senatorów z Mazowsza i Podlasia wśród wyborców Władysława IV

\begin{tabular}{|c|c|c|c|c|c|c|c|c|}
\hline \multirow[t]{2}{*}{ Senatorowie } & \multicolumn{2}{|c|}{$\begin{array}{l}\text { Uczestnik } \\
\text { elekcji }\end{array}$} & \multicolumn{2}{|c|}{$\begin{array}{c}\text { Elektor } \\
\text { Władysława IV }\end{array}$} & \multicolumn{2}{|c|}{$\begin{array}{l}\text { Nieobecny na } \\
\text { sejmie elekcyjnym }\end{array}$} & \multicolumn{2}{|c|}{$\begin{array}{c}\text { Ustawowy skład se- } \\
\text { natu dla Mazowsza } \\
\text { i Podlasia }\end{array}$} \\
\hline & 1.b. & $\%$ & l.b. & $\%$ & 1.b. & $\%$ & 1.b. & $\%$ \\
\hline Biskupi & 1 & 100,0 & 1 & 100,0 & 0 & 0,0 & 1 & 100,0 \\
\hline Wojewodowie & 3 & 75,0 & 3 & 75,0 & 1 & 25,0 & 4 & 100,0 \\
\hline $\begin{array}{l}\text { Kasztelanowie } \\
\text { więksi }\end{array}$ & 4 & 100,0 & 4 & 100,0 & 0 & 0,0 & 4 & 1000 \\
\hline Kasztelanowie & & & & & & & & \\
\hline mniejsi & 5 & 62,5 & 4 & 50,0 & 3 & 37,5 & 8 & 100,0 \\
\hline Razem & 13 & 76,5 & 12 & 70,6 & 4 & 23,5 & 17 & 100,0 \\
\hline
\end{tabular}

Kolejną grupą wyborców Władysława IV byli urzędnicy ziemscy. W tej grupie wyróżniamy następujące urzędy według ich starszeństwa: podkomorzy, chorąży, sędzia, stolnik, podczaszy, podsędek, podstoli, cześnik, lowczy, wojski, pisarz, miecznik, skarbnik, komornik, podwojewodzi, leśniczy i żupnik.

$Z$ analizy statystycznej wynika, że urzędnicy ziemscy stanowili $10,1 \%$ ogółu wyborców nowego króla. $Z$ kolei w grupie wyborców utytułowanych stanowili aż $57,9 \%{ }^{46}$. Na tym tle urzędnicy ziemscy z Mazowsza i Podlasia (135) stanowili $3,8 \%$ w stosunku do wszystkich wyborców nowego króla. Natomiast w grupie 618 elektorów utytułowanych stanowili oni $21,9 \%$, wśród koroniarzy (475) posiadających tytuły $-28,4 \%$, a w grupie 199 elektorów z Mazowsza i Podlasia urzędnicy ziemscy stanowili 67,8\%. Największą grupe wśród mazowieckich i podlaskich urzędników ziemskich stanowili: pisarze $-9,6 \%$, chorążowie $-8,9 \%$, podkomorzowie, podczaszowie i stolnicy $-7,4 \%$,

${ }^{46} \mathrm{~W} . \mathrm{K}$ a c zor ow ski, Wielkopolanie..., s. 185. 
skarbnicy $-3,7 \%$, natomiast najmniejszą grupę stanowili: miecznicy $-2,2 \%$, leśniczowie i żupnicy - po $0,7 \%$. Zestawienie liczby urzędników ziemskich z Mazowsza i Podlasia ilustruje tabela 5.

Tabela 5: Mazowieccy i podlascy urzędnicy ziemscy wśród elektorów Władysława IV zestawieni według ważności urzędów ziemskich

\begin{tabular}{|l|c|c|}
\hline \multicolumn{1}{|c|}{ Urząd ziemski } & 1. b. & $\%$ \\
\hline Podkomorzy & 10 & 7,4 \\
Chorąży & 12 & 8,9 \\
Sędzia & 9 & 6,7 \\
Stolnik & 10 & 7,4 \\
Podczaszy & 10 & 7,4 \\
Podsędek & 10 & 7,4 \\
Podstoli & 9 & 6,7 \\
Cześnik & 8 & 5,9 \\
Lowczy & 9 & 6,7 \\
Wojski & 11 & 8,2 \\
Pisarz & 13 & 9,6 \\
Miecznik & 3 & 2,2 \\
Skarbnik & 5 & 3,7 \\
Komornik & 9 & 6,7 \\
Podwojewodzi & 5 & 3,7 \\
Leśniczy & 1 & 0,7 \\
Zupnik & 1 & 0,7 \\
\hline Razem & 135 & 100,0 \\
\hline
\end{tabular}

Urzędnicy ziemscy $z$ Mazowsza $w$ podziale na województwa i ziemie, usystematyzowani według starszeństwa urzędu.

- Woj. mazowieckie, ziemia czerska

Podkomorzy czerski - Zygmunt Parys; chorąży czerski - Zygmunt Oborski; sędzia czerski - Mikołaj Boglewski; stolnik czerski - Bartłomiej Grabianka ${ }^{47}$; podczaszy czerski - Krzysztof Opacki ${ }^{48}$; podsędek czerski - Jan Całowański; łowczy czerski - Jerzy Leżeński; wojski czerski - Seweryn Kurdwanowski; podwojewodzi czerski - Aleksander Magnuszewski; podwojewodzi warszawski - Jan Walbach ${ }^{49}$.

- Woj. mazowieckie, ziemia warszawska

Podkomorzy warszawski - Zygmunt Opacki; chorąży warszawski - Wojciech Opacki; sędzia warszawski - Teofil Grzybowski; stolnik warszawski - Wojciech

${ }^{47}$ Bartłomiej Grabianka - stolnik czerski, podpisał się dwukrotnie: z ziemią czerską i ziemią warszawska.

${ }^{48}$ Krzysztof Opacki - podczaszy czerski, podpisal się dwukrotnie: z ziemią czerską i ponownie $\mathrm{z}$ ziemią wiska.

49 Jan Walbach - podwojewodzi warszawski, podpisał się z ziemią czerską. 
Gliniecki; podsędek warszawski - Wojciech Świeszewski; cześnik warszawski - Stanisław Gloskowski; lowczy warszawski - Wiktorian Krzyżanowski; wojski warszawski - Andrzej Mokronowski; pisarz warszawski - Kasper Rusiecki; skarbnik warszawski - Andrzej Prażmowski ${ }^{50}$.

- Woj. mazowieckie, ziemia wiska

Podkomorzy wiski - Jakub Grajewski; sędzia wiski - Jan Mocarski; cześnik wiski - Andrzej Kossakowski; łowczy wiski - Kazimierz Brzostowski; pisarz wiski - Adam Glinka Januszewski.

- Woj. mazowieckie, ziemia wyszogrodzka

Podkomorzy wyszogrodzki - Adam Wilkanowski; chorąży wyszogrodzki - Andrzej Niszczycki; stolnik wyszogrodzki - Jakub Kobylnicki; podsędek wyszogrodzki - Marcin Ciołkowski; cześnik wyszogrodzki - Mikołaj Wilkanowski; wojski wyszogrodzki - Andrzej Nakwaski; skarbnik wyszogrodzki - Adrian Nieborski; podwojewodzi wyszogrodzki - Marcjan Sarnowski.

- Woj. mazowieckie, ziemia zakroczymska

Podkomorzy zakroczymski - Mikołaj Łopacki; chorąży zakroczymski - Stanisław Skaszewski; stolnik zakroczymski - Adam Bieliński; podczaszy zakroczymski - Jan Rybski; wojski zakroczymski - Wojciech Lelewski; pisarz zakroczymski - Krzysztof Brochowski; miecznik sochaczewski - Adam Szeczemski ${ }^{51}$; komornik zakroczymski - Jakub Godaczewski; podwojewodzi zakroczymski - Stanislaw Szczypierski.

- Woj. mazowieckie, zicmia ciechanowska

Chorąży ciechanowski - Krzysztof Narzymski; sędzia ciechanowski - Stanisław Krasicki; stolnik ciechanowski - Stanisław Młocki; cześnik ciechanowski - Wojciech Gołyński; lowczy ciechanowski - Wawrzyniec Godzimiński; pisarz ciechanowski - Jan Kukliński.

- Woj. mazowieckie, ziemia lomżyńska

Podkomorzy łomżyński - Piotr Zamoyski; chorąży łomżyński - Szczęsny Iłowski; sędzia łomżyński - Jan Olszewski; podczaszy wiski - Aleksander Iłowski ${ }^{52}$; podsędek lomżyński - Szymon Milewski; podstoli łomżyński - Stanisław Iłowski; cześnik lomżyński - Stanisław Laskowski; wojski lomżyński - Adam Bagiński; pisarz łomżyński - Stanisław Baranowski; pisarz zambrowski - Aleksander Meżyński.

- Woj. mazowieckie, ziemia różańska

Podczaszy różański - Stanisław Glinka; podstoli różański - Jakub Glinka; komornik różański - Wojciech Krzyżewski.

\footnotetext{
so Andrzej Prażmowski - skarbnik warszawski, podpisał się dwukrotnie, z ziemią warszawską i ziemią czerską.

${ }^{51}$ Adam Szeczemski - miecznik sochaczewski, podpisał się z ziemią zakroczymską.

${ }^{52}$ Aleksander Iłowski - podczaszy wiski, podpisał się z ziemią łomżyńską.
} 
- Woj. mazowieckie, ziemia liwska

Podkomorzy liwski - Stanisław Cieciszewski; chorąży liwski - Jacynt Młodziejowski; sędzia liwski - Wojciech Zaliwski; podstoli liwski - Abram Cieciszewski; wojski liwski - Jan Zabicki; skarbnik liwski - Maciej Broszkowski.

- Woj. mazowieckie, ziemia nurska

Podkomorzy nurski - Stanisław Brzoska; chorąży nurski - Jakub Pogorzelski; sędzia nurski - Walenty Niedziałkowski; stolnik nurski - Jan Olecki; podczaszy nurski - Jachym Brzoska; podsędek nurski - Wojciech Woliński; podstoli nurski - Zbigniew Ossoliński ${ }^{53}$; podstoli drohicki - Stanisław Chadziński ${ }^{54}$; lowczy nurski - Mikolaj Radzyński; wojski nurski - Mateusz Woliński; pisarz nurski - Szymon Jabłonowski; skarbnik nurski - Lukasz Sutkowski; komornik nurski - Jarosz Grodzicki; komornik nurski - Wawrzyniec Wyszomierski.

- Woj. płockie

Chorąży płocki - Marcin Radzanowski; sędzia płocki - Stanisław Kryski; stolnik płocki - Jan Zieliński; podczaszy płocki - Stanisław Piwo; podczaszy dobrzyński - Andrzej Kruszowski ${ }^{55}$; podsędek zawkrzyński - Jan Zaborowski; podstoli płocki - Grzegorz Kęczewski; lowczy płocki - Jakub Kosmaczewski; pisarz zawkrzyński - Wojciech Drozdowski; miecznik ciechanowski - Stanisław Szarbiewski ${ }^{56}$; skarbnik plocki - Stanisław Kłokocki.

- Woj. podlaskie ${ }^{57}$

Podkomorzy drohicki - Marek Wodyński; podkomorzy mielnicki - Gabriel Jerzykowic; sędzia mielnicki - Adam Raczko; podczaszy podlaski - Stanislaw Lewicki; podsędek mielnicki - Jan Biernacki; podstoli podlaski - Jan Karp; podstoli sanocki - Samuel Umiński; cześnik podlaski - Krzysztof Brzozowski; wojski drohicki - Jan Puchalski; wojski mielnicki - Stanisław Mogiliński; pisarz mielnicki - Jan Trojanowski; pisarz bielski - Krzysztof Brzozowski; komornik drohicki - Jan Zaleski; komornik bielski - Panteleon Lyczko; komornik mielnicki - Sebastian Tarkowski; leśniczy merecki - Pawel Niewiarowski.

- Woj. rawskie, ziemia rawska

Chorąży rawski - Piotr Załuski; stolnik rawski - Grzegorz Dunin; podczaszy rawski - Jan Krosnowski; podsędek rawski - Melchior Luba Głaczyński; cześnik rawski - Wawrzyniec Załuski; wojski rawski - Maciej Lipski; pisarz

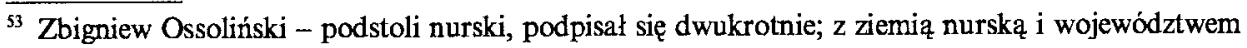
podlaskim.

${ }^{54}$ Stanisław Chadziński - podstoli drohicki, podpisał się z ziemią nurską.

${ }^{\text {ss }}$ Andrzej Kruszowski - podczaszy dobrzyński, podpisał się z województwem płockim.

${ }^{56}$ Stanisław Szarbiewski - miecznik ciechanowski, podpisał się z województwem płockim.

${ }^{57}$ Stanisław Aleksander Łoknicki - wojski brzeski, podpisał się dwukrotnie: z województwem brzeskim i podlaskim. 
rawski - Mikolaj Łajszczewski; komornik rawski - Jan Świejkowski; podwojewodzi rawski - Lukasz Bronowski; zupnik rawski - Seweryn Kurzeski.

- Woj. rawskie, ziemia sochaczewska

Chorąży sochaczewski - Kasper Lipski; stolnik sochaczewski - Józef Stamirowski; podsędek sochaczewski - Stanisław Nieborowski; podstoli sochaczewski - Stanisław Plichta; lowczy sochaczewski - Andrzej Pudłowski; wojski sochaczewski - Stanisław Chodakowski; pisarz sochaczewski - Adam Brochowski; komornik sochaczewski -- Tomasz Badowski.

- Woj. rawskie, ziemia gostyńska

Chorąży gostyński - Marcjan Bykowskii ${ }^{58}$; stolnik gostyński - Wojciech Stępowski; podczaszy gostyński - Wawrzyniec Stamirowski; podsędek gostyński - Rafal Grabski; cześnik gostyński - Stefan Ciechomski; lowczy gostyński - Florian Stępowski; łowczy dobrzyński - Piotr Piwo ${ }^{59}$; pisarz gostyński - Wojciech Kacki; miecznik gostyński - Wawrzyniec Podczaski.

Trzecią grupą utytułowanych wyborców Władysława IV byli urzędnicy grodzcy. Stanowili oni $2,6 \%$ wyborców Władysława IV, natomiast w grupie wyborców utytułowanych stanowili $15,1 \%$. Mazowieccy i podlascy urzędnicy grodzcy stanowili 0,9\% wśród wyborców nowego króla. Wśród 618 elektorów utytułowanych Władyslawa IV, stanowili $5,2 \%, \mathrm{z}$ kolei wśród utytułowanych elektorów z Korony (475), urzędnicy grodzcy stanowili 6,7\%. $\mathrm{Na}$ tle reprezentacji mazowieckiej i podlaskiej (199) wśród wyborców nowego króla, urzędnicy grodzcy stanowili 16,1\%. Najliczniejsza grupe spośród mazowieckich i podlaskich urzędników grodzkich stanowili starostowie - 53,1\%, podstarostowie - 34,4\%, natomiast najmniej liczni byli pisarze grodzcy $-9,4 \%$ i burgrabiowie $-3,1 \%$. Powyższe obliczenia ukazuje tabela 6.

Tabela 6: Urzędnicy grodzcy z Mazowsza i Podlasia wśród elektorów Władysława IV

\begin{tabular}{|l|c|c|}
\hline \multicolumn{1}{|c|}{ Urząd grodzki } & $1 . b$. & $\%$ \\
\hline Starosta grodowy & 17 & 53,1 \\
Podstarości & 11 & 34,4 \\
Pisarz grodzki & 3 & 9,4 \\
Burgrabia & 1 & 3,1 \\
\hline Razem & 32 & 100,0 \\
\hline
\end{tabular}

\footnotetext{
${ }^{58}$ Marcjan Bykowski - chorąży gostyński, podpisał się dwukrotnie: z ziemią gostyńską i województwem sieradzkim.

${ }^{59}$ Piotr Piwo - lowczy dobrzyński, podpisał się z ziemią gostyńską.
} 
A oto wykaz mazowieckich i podlaskich urzędników grodzkich z podziałem na województwa $\mathrm{i}$ ziemie:

Woj. mazowieckie, ziemia czerska

Starosta czerski - Adam Hieronim Parys; podstarości czerski - Kasper Rykalski.

- Woj. mazowieckie, ziemia warszawska

Starosta warszawski - Stefan Dobrogost Grzybowski; podstarości warszawski - Jan Nagorka.

- Woj. mazowieckie, ziemia wiska

Starosta wiski - Mikołaj Kosakowski; starosta gołbiński - Jan Kosakowski; podstarości wąsoski - Jan Świderski; podstarości wiski - Maciej Grądzki.

Woj. mazowieckie, ziemia wyszogrodzka

Starosta wyszogrodzki - Michał Karnkowski; podstarości wyszogrodzki - Walenty Duplicki.

- Woj. mazowieckie, ziemia ciechanowska

Starosta ciechanowski - Jakub Podolski; starosta janowski - Jan Duczymiński; podstarości ciechanowski - Stanisław Slubowski.

- Woj. mazowieckie, ziemia lomżyńska

Starosta łomżyński - Piotr Zamoyski; podstarości zambrowski - Jakub Pietka Sobolewski.

- Woj. mazowieckie, ziemia różańska

Starosta różański - Wojciech Wesel Różański.

- Woj. mazowieckie, ziemia liwska

Starosta liwski - Jan Oborski; podstarości liwski - Jan Wierzbicki.

Woj. mazowieckie, ziemia nurska

Starosta nurski - Jan Chodziński; podstarości nurski - Marcin Milewski.

- Woj. płockie

Starosta płocki - Ludwik Krasiński; starosta bobrownicki - Jan Cerski; pisarz grodzki płocki - Pawel Kargowski.

- Woj. podlaskie

Starosta brański - Prokop Leśniowolski; podstarości mielnicki - Wojciech Kochański; podstarości drohicki - Mateusz Rokitnicki; burgrabia mielnicki - Adam Hornowski; pisarz grodzki brański - Mikolaj Bruszewski.

- Woj. rawskie, ziemia rawska

Starosta rawski - Sebastian Wołucki; pisarz grodzki radomski - Jakub Rogowski.

- Woj. rawskie, ziemia gostyńska

Starosta gostyński - Oktawian Plichta; starosta stanisławowski - Piotr Małachowski.

Wśród utytułowanych elektorów Władysława IV znaleźli się również urzędnicy dworscy. Stanowili oni 1,9\% ogółu elektorów, natomiast w kategorii wyborców utytułowanych stanowili $10,8 \%$, w tym koronni $-8,7 \%$, a litewscy 
- 2,1\%. Urzędników dworskich z Mazowsza i Podlasia było 20, co stanowiło w grupie 618 wyborców utytułowanych 3,2\%, wśród Koroniarzy (475) - 4,2\%, a na tle utytułowanych Mazowszan i Podlasian - 10,1\%. Najliczniejszą grupę spośród mazowieckich i podlaskich urzędników dworskich stanowili: dworzanie królewscy - 45,0\%, sekretarze królewscy - 20,0\%, natomiast najmniej liczni byli komornicy królewscy i pisarze królewscy - po 5,0\%.

W kategorii urzędników dworskich $\mathrm{z}$ Mazowsza i Podlasia zabrakło reprezentantów z ziem: wyszogrodzkiej, różańskiej, nurskiej i sochaczewskiej. Powyższe obliczenia przedstawia tabela 7 .

Tabela 7: Mazowieccy i podlascy urzędnicy dworscy wśród elektorów Wladyslawa IV

\begin{tabular}{|l|c|c|}
\hline \multicolumn{1}{|c|}{ Urząd dworski } & 1.b. & $\%$ \\
\hline Stanowniczy & 1 & 5,0 \\
Dworzanin królewski & 9 & 45,0 \\
Komornik królewski & 1 & 5,0 \\
Sekretarz królewski & 4 & 20,0 \\
Pokojowy królewski & 2 & 10,0 \\
Pisarz królewski & 1 & 5,0 \\
Pisarz skarbowy & 2 & 10,0 \\
\hline Razem & 20 & 100,0 \\
\hline
\end{tabular}

A oto wykaz mazowieckich i podlaskich urzędników dworskich w podziale na województwa i ziemie:

noj. mazowieckie, ziemia czerska

Stanowniczy królewski - Jakub Aleksander Biedrzycki; dworzanin królewski - Jan Prażmowski; dworzanin królewski - Pawel Warszycki; dworzanin królewski - Janusz Oborski; komornik królewski - Jan Szczęsny Prażmowski.

- Woj. mazowieckie, ziemia warszawska

Sekretarz królewski - Wawrzyniec Prażmowski; dworzanin królewski - Władysław Zdzarski.

Woj. mazowieckie, ziemia wiska

Pokojowy królewski - Andrzej Kosakowski.

- Woj. mazowieckie, ziemia zakroczymska

Dworzanin królewski - Hieronim Gołyński; dworzanin królewski - Konstanty Golyński.

- Woj. mazowieckie, ziemia ciechanowska

Dworzanin królewski - Adam Niszczycki; pokojowy królewski - Jan Kazimierz Krasicki.

- Woj. mazowieckie, ziemia lomżyńska

Pisarz królewski - Mikolaj Choromański.

- Woj. mazowieckie, ziemia liwska

Sekretarz królewski - Jakub Kazimierz Żabicki. 
Woj. płockie

Sekretarz królewski - Jan Racibor Starczewski.

- Woj. podlaskie

Pisarz skarbowy - Samuel Korzuchowski; pisarz skarbowy - Stanisław Piotrowski.

- Woj. rawskie, ziemia rawska

Sekretarz królewski - Mikołaj Krosnowski.

Woj. rawskie, ziemia sochaczewska

Dworzanin królewski - Marcin Nieborowski; dworzanin królewski

- Mikolaj Radziejowski.

Utytułowanych elektorów mazowieckich i podlaskich przedstawia tabela 8 .

Podsumowując powyższe wyliczenia, możemy stwierdzić, przyjmując jednak we wszystkich przedstawionych wyliczeniach pewien margines błędu, że:

1. Na liczbę 3543 elektorów Władysława IV, reprezentacja Mazowsza i Podlasia liczyła 1132 swych przedstawicieli, co stanowiło $32 \%$ ogółu suffragatorów. Na trzech elektorów z pozostałych województw koronnych i litewskich przypadal jeden reprezentant Mazowsza i Podlasia.

2. Na liczbę 2847 elektorów z Korony, Mazowszanie i Podlasianie (1 132) stanowili $39,8 \%$; w przybliżeniu na trzech elektorów z Korony przypadał jeden reprezentant Mazowsza i Podlasia.

3. Z kolei w układzie globalnym Mazowszanie i Podlasianie posiadali 199 elektorów utytułowanych, co stanowiło $32,2 \%$ ogółu wyborców utytułowanych, pozostałe województwa koronne liczyły 44,7\%, a litewskie $-23,1 \%$. Na trzech elektorów utytułowanych $\mathrm{z}$ pozostałych województw koronnych i litewskich przypadal jeden reprezentant $z$ Mazowsza i Podlasia.

4. W grupie wyborców utytułowanych z Korony, Mazowszanie i Podlasianie stanowili $41,9 \%$, a elektorzy z pozostałych województw koronnych $-58,1 \%$, czyli $w$ przybliżeniu na dwóch elektorów $\mathrm{z}$ Korony przypadal jeden reprezentant Mazowsza i Podlasia.

5. Poszczególny stan grup elektorów utytułowanych z Mazowsza i Podlasia kształtowal się następująco: urzędnicy ziemscy $-67,8 \%$, urzędnicy grodzcy - 16,1 , urzędnicy dworscy $-10,1 \%$ i senatorowie $-6,0 \%$.

6. W poszczególnych kategoriach wyżej wymienionych grup elektorów najliczniej zaprezentowali się: wśród senatorów - kasztelanowie więksi $(33,3 \%)$; wśród urzędników ziemskich - pisarze $(9,6 \%)$; wśród urzędników grodzkich - starostowie grodowi $(53,1 \%)$; wśród urzędników dworskich - dworzanie $(45,0 \%)$.

W wyborze polskich królów elekcyjnych brało udział od kilkudziesięciu tysięcy elektorów (w roku 1573, 1575, 1587, 1669) do 3,5 tys. w roku 1632. Stanowiło to - jak wyliczył J. Dzięgielewski - (pomijając pierwszą elekcję) ok. 6-7\% ogółu uprawnionych. Niewielka liczba elektorów zjawiła się na 
Tabela 8: Utytułowani elektorzy mazowieccy i podlascy (senatorowie, urzędnicy ziemscy, grodzcy i dworscy) na tle województw i ziem

\begin{tabular}{|c|c|c|c|c|c|c|c|c|c|c|}
\hline \multirow{3}{*}{$\begin{array}{l}\text { Województwo, } \\
\text { ziemia }\end{array}$} & \multicolumn{8}{|c|}{ Elektorzy utytułowani } & \multirow{2}{*}{\multicolumn{2}{|c|}{ Razem }} \\
\hline & \multicolumn{2}{|c|}{ senatorowie } & \multicolumn{2}{|c|}{ urzędnicy ziemscy } & \multicolumn{2}{|c|}{ urzędnicy grodzcy } & \multicolumn{2}{|c|}{ urzednicy dworscy } & & \\
\hline & 1.b. & $\%$ & 1.b. & $\%$ & 1.b. & $\%$ & 1.b. & $\%$ & 1.b. & $\%$ \\
\hline $\begin{array}{l}\text { Woj. mazowieckie } \\
\text { z. czerska }\end{array}$ & 2 & 10,5 & 10 & 52,6 & 2 & 10,5 & 5 & 26,4 & 19 & 100,0 \\
\hline $\begin{array}{l}\text { Woj. mazowieckie } \\
\text { z. warszawska }\end{array}$ & - & - & 10 & 71,4 & 2 & 14,3 & 2 & 14,3 & 14 & 100,0 \\
\hline $\begin{array}{l}\text { Woj. mazowieckie } \\
\text { z. wiska }\end{array}$ & - & - & 5 & 50,0 & 4 & 40,0 & 1 & 10,0 & 10 & 100,0 \\
\hline $\begin{array}{l}\text { Woj. mazowieckie } \\
\text { z. wyszogrodzka }\end{array}$ & 1 & 9,1 & 8 & 72,7 & 2 & 18,2 & - & - & 11 & 100,0 \\
\hline $\begin{array}{l}\text { Woj. mazowieckie } \\
\text { z. zakroczymska }\end{array}$ & 1 & 8,3 & 9 & 75,0 & - & - & 2 & 16,7 & 12 & 100,0 \\
\hline $\begin{array}{l}\text { Woj. mazowieckie } \\
\text { z. ciechanowska }\end{array}$ & - & - & 6 & 54,6 & 3 & 27,3 & 2 & 18,1 & 11 & 100,0 \\
\hline $\begin{array}{l}\text { Woj. mazowieckie } \\
\text { z. łomżyńska }\end{array}$ & - & - & 10 & 76,9 & 2 & 15,4 & 1 & 7,7 & 13 & 100,0 \\
\hline $\begin{array}{l}\text { Woj. mazowieckie } \\
\text { z. różańska }\end{array}$ & - & - & 3 & 75,0 & 1 & 25,0 & - & - & 4 & 100,0 \\
\hline $\begin{array}{l}\text { Woj. mazowieckie } \\
\text { z. liwska }\end{array}$ & 1 & 10,0 & 6 & 60,0 & 2 & 20,0 & 1 & 10,0 & 10 & 100,0 \\
\hline $\begin{array}{l}\text { Woj. mazowieckie } \\
\text { z. nurska }\end{array}$ & - & - & 14 & 87,5 & 2 & 12,5 & - & - & 16 & 100,0 \\
\hline Woj. plockie & 3 & 16,7 & 11 & 61,1 & 3 & 16,7 & 1 & 5,5 & 18 & 100,0 \\
\hline Woj. podlaskie & 1 & 4,2 & 16 & 66,7 & 5 & 20,8 & 2 & 8,3 & 24 & 100,0 \\
\hline $\begin{array}{l}\text { Woj. rawskie } \\
\text { z. rawska }\end{array}$ & 2 & 13,3 & 10 & 66,7 & 2 & 13,3 & 1 & 6,7 & 15 & 100,0 \\
\hline $\begin{array}{l}\text { Woj. rawskie } \\
\text { z. sochaczewska }\end{array}$ & 1 & 9,1 & 8 & 72,7 & - & - & 2 & 18,2 & 11 & 100,0 \\
\hline $\begin{array}{l}\text { Woj. rawskie } \\
\text { z. gostyńska }\end{array}$ & - & - & 9 & 81,8 & 2 & 18,2 & - & - & 11 & 100,0 \\
\hline Razem & 12 & 6,0 & 135 & 67,8 & 32 & 16,1 & 20 & 10,1 & 199 & 100,0 \\
\hline
\end{tabular}


sejm elekcyjny i elekcje w roku 1632, gdyż mieli oni w rzeczywistości potwierdzić tylko wybór jedynego kandydata królewicza Władysława Wazę $e^{60}$.

Poza zaprezentowanymi wyliczeniami, pożyteczny będzie zamieszczony imienny wykaz nieutytułowanych elektorów Wladysława IV, reprezentujących Mazowsze i Podlasie. Można uznać reprezentację nieutytułowanych elektorów z Mazowsza i Podlasia za liczną, wśród nieutytułowanych wyborców Władysława IV, gdyż na 2925 elektorów Władysława IV, Mazowszanie i Podlasianie posiadali 933 swoich przedstawicieli, co stanowi 31,9\%. Można zatem przyjąć prawidłowość, że na trzech elektorów nieutytułowanych $\mathrm{z}$ pozostałych województw koronnych $\mathrm{i}$ litewskich przypadał jeden wyborca reprezentujący Mazowsze i Podlasie. Zamieszczamy również wykaz nieutytułowanych elektorów z Mazowsza i Podlasia (zob. aneks).

\section{Aneks: Wykaz mazowieckich i podlaskich nieutytulowanych elektorów Wladyslawa IV - w podziale na województwa i ziemie}

\section{- Ziemia czerska, województwo mazowieckie}

1. Biejkowski Abram

2. Błędowski Jan

3. Blędowski Piotr

4. Boski Dobrogost

5. Byczyński Jakub

6. Całowański Aleksander

7. Całowański Stanisław

8. Cieciszewski Seweryn

9. Gliniecki Stanisiaw

10. Grabianka Jan

11. Goliański Mateusz

12. Jahodyński Andrzej

13. Jedwabiński Stanisław

14. Kobylski Mikołaj

15. Koziełkowski Mikolaj

16. Krasowski Tomasz

17. Leśniowolski Jan

18. Leżeński Marian

19. Lisowski Arnold

20. Lisowski Felicjan

21. Lisowski Jan

22. Lisowski Kasper

23. Loski Adrian

24. Machnacki Marcjan
25. Magnuszewski Jan

26. Oborski Jan

27. Oborski Kaspar

28. Oborski Konstanty Janusz

29. Oborski Marian

30. Oborski Stanisław

31. Oczosalski Andrzej

32. Ogrodziński Jan

33. Ogrodziński Walerian

34. Olszewski Stanisław

35. Opacki Mikołaj

36. Opacki Wojciech

37. Parys Andrzej Hieronim

38. Pilik Wawrzyniec

39. Pracki Adam

40. Prażmowski Adam

41. Prażmowski Marcin

42. Prażmowski Marcjan

43. Prażmowski Mikołaj

44. Prażmowski Olbrycht

45. Prażmowski Piotr

46. Prażmowski Remigiusz Otto

47. Prażmowski Wawrzyniec

48. Raciborski Marcin

60 J. Dzięgi ie lewski, Sejmy elekcyjne..., s. 202-203. 
49. Raciborski Walerian

50. Rudzki Wojciech

51. Rykaiski Kasper

52. Rykalski Kasper

53. Staniszewski Jakub

54. Staniszewski Kasper

55. Staniszewski Tobiasz
56. Staniszewski Trojan

57. Trzebiński Zygmunt

58. Uleniecki Florian

59. Uleniecki Jan

60. Uwieliński Jan

61. Wieszczycki Chryzostom

62. Zawisza Abram

\section{- Ziemia warszawska, województwo mazowieckie}

1. Chrzanowski Andrzej

2. Głuchowski Marcin

3. Golkowski Marcjan

4. Gorzeszkot Krzysztof

5. Gorzeszkot Remian

6. Gorzyszkot Samuel

7. Grot Maciej

8. Grzybowski Jan

9. Jezierzyński Stanisław

10. Jezierzyński Wojciech

11. Jeziorkowski Adam

12. Jeziorkowski Wojciech

13. Kłodziński Jakub

14. Kołczyński Jan

15. Kołczyński Wojciech

16. Kotowski Kazimierz

17. Kukliński Jakub

18. Mirowski Jan

19. Mokronowski Wojciech

20. Nagorka Adrian

21. Nietyksa Marcjan

22. Nietyksa Mikołaj

23. Nityksa Teofil

24. Nowodworski Jerzy

25. Okęcki Jan

26. Opacki Jarosz

27. Opacki Wojciech Ignacy

28. Osuchowski Walenty

29. Otrębus Andrzej

30. Parzniewski Jan

31. Pechawski Krzysztof

32. Petkowski Adam

33. Petrykowski Marcin
34. Petrykowski Walerian

35. Plochocki Adam

36. Płochocki Jan

37. Plochocki Marcjan

38. Płochocki Sebastian

39. Prażmowski Adam

40. Rakowski Maksymilian

41. Rakowski Tomasz

42. Reczajski Wojciech

43. Rembieliński Andrzej

44. Rembieliński Dobrogost

45. Rembieliński Stanisław

46. Rusiecki Albert

47. Rusiecki Krzysztof

48. Rusiecki Marcjan

49. Rylski Spytek

50. Stańczewski Jan

51. Sławoszowski Mikołaj

52. Stamirowski Józef

53. Stanclewski Marcin

54. Staniszewski Krzysztof

55. Święcicki Jacek

56. Swięcicki Jakub

57. Swięcicki Kasper

58. Swięcicki Kazimierz

59. Swięcicki Ludwik

60. Swięcicki Stanisław

61. Swięcicki Wojciech

62. Zaleski Remigian

63. Zaremba Marcin

64. Zdzarski Jan

65. Zieleński Mikołaj

\section{Ziemia wiska, województwo mazowieckie}

\author{
1. Barzykowski Jan \\ 2. Barzykowski Krzysztof \\ 3. Brodowski Wojciech \\ 4. Brunak Jan \\ 5. Brunak Maciej
}

6. Brzostowski Adam

7. Brzostowski Maciej

8. Brzostowski Wojciech

9. Burzyński Wojciech

10. Chrostowski Augustyn 

11. Chyliński Marcin
12. Doliwa Samuel
13. Drozdowski Gabriel
14. Glinka Pawel
15. Glinka Tomasz
16. Grajewski Jan
17. Grodzki Zygmunt
18. Grot Wojciech Biedrzycki
19. Jedwabiński Stanisław
20. Jeziorkowski Adam
21. Jeziorkowski Wojciech
22. Karwowski Adam
23. Karwowski Jan
24. Karwowski Józef
25. Karwowski Wojciech
26. Kosakowski Jan
27. Kosakowski Władysław
28. Kostkowski Adam
29. Kraszewski Stanisław
30. Kuczewski Kasper
31. Kuczewski Piotr
32. Kuczewski Stefan
33. Kuczewski Wojciech
34. Lawski Jan
35. Lawski Stanisław
36. Lepicki Stanisław
37. Leppicki Wojciech
38. Lojewski Andrzej
39. Mazowski Mikołaj
40. Miński Maciej
41. Mocarski Jan
42. Olszyński Jan
43. Olszyński Stanisław
44. Pieńkowski Paweł
45. Rogalski Maciej
46. Stucki Stefan
47. Stajewski Aleksander
48. Szczuka Jan
49. Swiderski Bartłomiej
50. Świderski Kasper
51. Swiderski Marcin
52. Truszkowski Maciej
53. Wierciszewski Wojciech
54. Wykowski Jan
55. Zaliwski Stanisław
56. Zamoyski Pawel
57. Zamoyski Wawrzyniec Ignacy
58. Zwonkowski Zygmunt

\section{- Ziemia wyszogrodzka, województwo mazowieckie}
1. Arciechowski Jakub
2. Glowański Szczęsny
3. Gomoński Andrzej
4. Hosius Stanisław
5. Kamieński Piotr
6. Kampo Gabriel
7. Kobylnicki Adam
8. Kobylnicki Rafał
9. Lasocki Tomasz
10. Lasocki Walenty
11. Lewicki Krzysztof

12. Nieborski Wojciech

13. Niszczycki Adam

14. Rybiński Mikołaj

15. Siromski Barttomiej

16. Trzciński Jerzy Szczęsny

17. Wilkanowski Piotr

18. Wilkanowski Zbigniew

19. Zarębiński Szczęsny

20. Zarębiński Zygmunt

21. Zbański Stanisław

\section{Ziemia zakroczymska, województwo mazowieckie}
1. Bieliński Mikołaj
2. Brochowski Jan
3. Grabia Wojciech Mazowski
4. Komorowski Grzegorz
5. Komorowski Jan
6. Komorowski Jan
7. Komorowski Stanisław
8. Koszewski Andrzej
9. Koszewski Piotr
10. Kowalewski Adam

11. Lagona Mikołaj

12. Lepicki Wawrzyniec

13. Lopacki Adam

14. Lopacki Jan

15. Nosilski Marcin Samuel

16. Pieściorocki Andrzej

17. Pijanowski Adam

18. Pniewski Wojciech

19. Pogorzelski Stefan

20. Radzicki Stanisław 
21. Rudnicki Jan

22. Źabicki Piotr

23. Zabicki Stefan

24. Żebrowski Stefan

25. Żeromski Jakub
26. Zeromski Kazimierz

27. Źeromski Marcin

28. Żeromski Tomasz Piotr

29. Żeromski Wojciech

\section{- Ziemia ciechanowska, województwo mazowieckie}

\section{Baranowicz Paweł}

2. Bieliński Franciszek

3. Biliński Jakub

4. Biliński Stanisław

5. Biliński Wojciech

6. Bogusławski Felicjan

7. Bogusławski Stanisław

8. Bogusławski Wojciech

9. Borusławski Stanisław

10. Brzozowski Jan

11. Chodupski Albert

12. Chołozemski Andrzej

13. Ciemniewski Krzysztof

14. Czernicki Szczęsny

15. Deszkowski Jan

16. Dzierszkowski Aleksander

17. Dzierzgowski Stanisław

18. Garliński Adam

19. Gawlowski Hieronim

20. Gliniecki Filip

21. Gnatowski Adam

22. Gnoiński Jakub

23. Gogolewski Jan

24. Gorski Jan

25. Gorski Tomasz

26. Gościmiński Zygmunt

27. Grabia Jakub

28. Grabia Mateusz

29. Grabowski Andrzej

30. Grabowski Paweł

31. Grabowski Stanisław

32. Grot Maciej

33. Gumowski Piotr

34. Kakowski Andrzej

35. Kakowski Jakub

36. Kakowski Wojciech

37. Kakowski Wojciech

38. Kamieński Piotr

39. Kanigowski Jan

40. Karleński Aleksander

41. Karwacki Kasper Kazimierz
42. Kijewski Wawrzyniec

43. Klicki Piotr

44. Konarzewski Mikołaj

45. Kroczewski Wojciech

46. Lagona Wojciech

47. Lipiński Stanisław

48. Lecki Gotert

49. Makowiecki Walenty

50. Mdzewski Piotr

51. Młocki Jan

52. Młodzianowski Dominik

53. Młodzianowski Jan

54. Mlodzianowski Maciej

55. Mlodzianowski Piotr

56. Młodzianowski Tomasz

57. Mosakowski Jan

58. Mosakowski Stanisław

59. Muchowiecki Zygmunt

60. Nieborski Marcin

61. Obrębski Mateusz

62. Pączkowski Andrzej

63. Pączkowski Bartosz

64. Pączkowski Marcin

65. Pączkowski Mikołaj

66. Peczyński Bartłomiej

67. Podolski Mateusz

68. Podosielodoski Pawel

69. Podoski Gaspar

70. Porębski Adam

71. Raczewski Stanisław

72. Radzicki Stanisław

73. Radziminski Marcin

74. Radzimiński Zygmunt

75. Roman Wojciech

76. Rombeliński Szczęsny

77. Rudziecki Mateusz Aleksander

78. Ryczycki Stanisław

79. Rydzewski Stanisław

80. Sarnowski Adam

81. Sierakowski Jakub

82. Slaski Adam 
83. Sokolnicki Mikołaj

84. Szarszewski Pawel

85. Szumowski Marcin

86. Szumski Jakub

87. Szumski Jan

88. Szumski Mikołaj

89. Slubowski Andrzej

90. Slubowski Antoni

91. Slubowski Franciszek

92. Slubowski Jakub

93. Slubowski Stanisław
94. Toluk Gaspar

95. Uiejski Sebastian

96. Umięcki Stanisław

97. Wolski Dunin Pawel

98. Wróblewski Wojciech

99. Zabłocki Piotr

100. Zbornski Dionizy

101. Zbroth Jan

102. Zochowski Adrian

103. Zochowski Piotr

104. Zochowski Ziemak

\section{- Ziemia lomżyńska, województwo mazowieckie}

1. Brzeski Wawrzyniec

2. Chojnacki Marcin

3. Czmalina Szymon

4. Dhugoborski Andrzej

5. Drozdowski Stanisław

6. Gałaska Jan

7. Golkowski Piotr

8. Grodzicki Stanisław

9. Ilowski Jan

10. Ilowski Jan

11. Iłowski Krzysztof

12. Ilowski Władysław

13. Jawor Michal

14. Jemielity Andrzej

15. Jemielity Wawrzyniec

16. Kołakowski Balcer

17. Kolakowski Jakub

18. Kołozębski Jan

19. Kowalewski Marcin

20. Krajewski Balcer
21. Krajewski Jakub

22. Kulikowski Jan

23. Laskowski Jakub

24. Laskowski Jan

25. Laskowski Mikołaj

26. Laskowski Mikołaj

27. Modzelowski Olbracht

28. Niszczycki Adam

29. Noskowski Marcin Stanisław

30. Pratnicki Andrzej

31. Prosiński Andrzej

32. Proszkowski Jan

33. Rostkowski Jarosz

34. Targowski Jan

35. Tyka Stanisław

36. Tyka Walenty

37. Zamoyski Wawrzyniec

38. Zubicki Adam

39. Żebrowski Piotr

\section{Ziemia różańska, województwo mazowieckie}

1. Biedrzycki Klimunt

2. Borek Pawel

3. Budzyński Daniel

4. Budzyński Jakub

5. Burzyński Jan

6. Chądzyński Wojciech

7. Chełczewski Pawel

8. Chrzanowski Andrzej

9. Chyliński Jan

10. Chyliński Wojciech

11. Damicki Adam

12. Damicki Jan

13. Dąbrowski Maciej

14. Dąbrowski Marcin
15. Glinka Adam

16. Glinka Maciej Wacław

17. Glinka Piotr

18. Glinka Stanisław

19. Głazewski Ostafi

20. Gorski Jakub

21. Iżycki Jan

22. Kamieński Jan

23. Karniewski Franciszek

24. Koczelski Wojciech

25. Kołakowski Jan

26. Kolakowski Stanisław

27. Kołakowski Zygmunt

28. Konarzewski Wojciech 
29. Krzyżewski Mateusz

30. Kuniński Krzysztof

31. Kuniński Wojciech

32. Mamiński Jakub

33. Mamiński Stanisław

34. Mierzejowski Marcjan

35. Miloński Jan

36. Miloński Wojciech

37. Mroczkowski Stanisław

38. Mrozowski Tomasz

39. Obrębski Kasper

40. Orzecki Stanisław

41. Postroski Andrzej

42. Rogowski Walenty

43. Romaszka Aleksander

44. Rostkowski Balcer

45. Rostkowski Jan
46. Rościszewski Jakub

47. Todowski Lukasz

48. Todowski Stanislaw

49. Wesel Franciszek

50. Wesel Janusz

51. Wesel Stanisław

52. Wieczejski Wojciech

53. Zabielski Jan

54. Zabielski Paweł

55. Zakliczewski Paweł

56. Zaleski Stanisław

57. Zaleski Wojciech

58. Zawacki Jan

59. Zdzarski Andrzej

60. Zebrowski Wojciech

61. Żyrański Wojciech

\section{- Ziemia liwska, województwo mazowieckie}

1. Biernacki Jarosz

2. Biernacki Marcin

3. Biernacki Pawel

4. Bożemski Aleksy

5. Bożemski Jan

6. Bożemski Krzysztof

7. Bożemski Mikołaj

8. Bożemski Stefan

9. Broszkowski Aleksander

10. Broszkowski Jan

11. Broszkowski Jan

12. Broszkowski Wojciech

13. Broszkowski Wojciech

14. Chmielecki Krzysztof

15. Dąbrowski Jakub

16. Dąbrowski Wojciech

17. Dobrzyniecki Krzysztof

18. Gostomski Stefan

19. Jabłoński Aleksander

20. Jabłoński Aleksander

21. Jabłoński Jan

22. Jabłoński Jarosz

23. Jabłoński Kasper

24. Jabłoński Krzysztof

25. Jabłoński Marcjan

26. Jabłoński Stanisław

27. Jabłoński Stanisław

28. Jastrzębski Mikołaj

29. Jastrzębski Stefan

30. Jeżewski Jan
31. Kobylski Piotr

32. Kobylski Tomasz

33. Krasuski Jakub

34. Lubiewski Adam

35. Lączyński Stanisław

36. Miaszkowski Jan

37. Mleczyński Jan

38. Niwicki Jarosz

39. Oborski Stanisław

40. Ostrowski Jan

41. Przygocki Stanisław

42. Smleński Kazimierz

43. Strzyżowski Prokop

44. Swiderski Pawel Kazimierz

45. Tuchowic Jan Kazimierz

46. Wagrocki Jan

47. Zaliwski Ignacy

48. Zaliwski Jacek

49. Zaliwski Jan

50. Zaliwski Jan

51. Zaliwski Kazimierz

52. Zaliwski Kazimierz

53. Zaliwski Stanisław

54. Zdzarski Jan

55. Zerek Hieronim

56. Zuchowski Stefan

57. Zukowski Jan

58. Zukowski Jan

59. Zabicki Stanislaw 


\section{- Ziemia nurska, województwo mazowieckie}

1. Bogucki Jan

2. Brzeziński Adam

3. Chodupski Wojciech

4. Czyżewski Wojciech

5. Ponikiewski Florian

6. Ponikiewski Stanisław

7. Ponikiewski Wojciech

8. Dmochowski Adam

9. Dmochowski Marcin

10. Dmochowski Piotr

11. Gliniecki Wawrzyniec

12. Gniewosz Jan

13. Gniewosz Mikołaj

14. Godlewski Adam

15. Godlewski Kasper

16. Gorski Jakub

17. Gorski Jan

18. Gorski Krzysztof

19. Gorski Krzysztof

20. Gorski Marcin

21. Gorski Samuel

22. Gostkowski Adrian

23. Gostkowski Kasper

24. Jeżewski Jan

25. Jabłonowski Nikodem

26. Jablonowski Stanisław

27. Jedwabiński Jan

28. Jedwabiński Stanisław

29. Karwacki Jan

30. Kleczkowski Jan

31. Kleczkowski Stanisław

32. Komorowski Jakub

33. Kosowski Bartosz

34. Kosowski Maciej

35. Krzeczkowski Jan

36. Kuniński Franciszek

37. Laskowski Marcin

38. Laskowski Olbrycht
39. Leśniewski Wojciech

40. Lipski Maciej

41. Łoś Jan

42. Lochowski Szymon

43. Lysakowski Stanisław

44. Mianowski Stanisław

45. Mianowski Wojciech

46. Nowodworski Jan

47. Pętkowski Adam

48. Pętkowski Jan

49. Pętkowski Piotr

50. Podbielski Sebastian

51. Podbielski Wojciech

52. Pogorzelski Tomasz

53. Ponikiewski Wojciech

54. Prosiński Jan

55. Przyborowski Jakub

56. Radzimiński Adrian

57. Radzimiński Ludwik

58. Radzimiński Pawel

59. Radzimiński Wawrzyniec

60. Sutkowski Jakub

61. Sutkowski Lukasz

62. Sutkowski Paweł

63. Sutkowski Stanisław

64. Sutkowski Wojciech

65. Swinołeski Wawrzyniec

66. Szeligowski Andrzej

67. Woliński Stefan

68. Woliński Wojciech

69. Wypyski Jan

70. Wysocki Aleksy

71. Wysocki Wawrzyniec

72. Wyszomierski Zachariasz

73. Zębocki Jan

74. Zębocki Marcin

75. Zębocki Stanisław

\section{- Województwo plockie}

1. Biliński Bonawentura

2. Biliński Stanisław

3. Bromierski Walerian

4. Brzeski Wojciech

5. Bycharski Stanisław

6. Chaliński Bartosz

7. Charyski Marcin

8. Chudziński Jan
9. Chudzyński Wawrzyniec
10. Czersnicki Szczęsny
11. Dembski Wojciech
12. Dłotowski Jan
13. Dramiński Marcjan
14. Dramiński Stefan
15. Drozdowski Maciej
16. Drozdowski Wawrzyniec 
17. Dzierżanowski Stanisław Grzymała

18. Gołebiowski Jakub

19. Gołyński Andrzej

20. Gołyński Andrzej

21. Grabia Marcjan

22. Jaroszowski Pawel

23. Kargowski Jan

24. Kargowski Stanisław

25. Karnkowski Stanisław

26. Karski Maciej

27. Kempski Mikołaj

28. Kęczewski Stanisław

29. Kosiński Jan

30. Kosobudzki Jakub

31. Kosobudzki Maciej

32. Kosobudzki Tomasz

33. Koświński Aleksander

34. Kozierowski Jakub

35. Krajewski Jakub

36. Krajewski Jan

37. Krajkowski Pawel

38. Krajowski Wawrzyniec

39. Krasinnski Stanisław

40. Krasowski Stanisław

41. Krasowski Tomasz

42. Krasowski Wojciech

43. Kraszewski Mateusz

44. Krzeciewski Maciej

45. Krzewski Jan

46. Krzewski Jarosz

47. Kucharski Maciej

48. Kucharski Piotr

49. Lempiński Jan

50. Lempiński Paweł

51. Loś Wojciech

52. Malewski Jan

53. Małużeński Wojciech

54. Mdzewski Stanisław

55. Mdzewski Stefan

56. Mdzewski Wojciech

57. Młocki Ludwik
58. Mysłkowski Stanisław

59. Narzymski Jakub

60. Narzymski Jan

61. Narzymski Mikołaj

62. Narzymski Stanisław

63. Nicki Gotard

64. Noskowski Stanisław

65. Przeciszewski Wojciech

66. Rościszewski Bartosz

67. Rościszewski Michal

68. Rościszewski Tomasz

69. Rościszewski Zygmunt

70. Rumocki Wojciech

71. Rycharski Hieronim

72. Rycharski Jan

73. Rycharski Wawrzyniec

74. Rydzewski Wojciech

75. Sarzewski Wojciech

76. Sielski Pawel

77. Skrobocki Jan

78. Skrobocki Maciej

79. Skrobocki Stanisław

80. Sławecki Piotr

81. Sławecki Walenty

82. Słostowski Jakub

83. Słucki Andrzej

84. Strzeszewski Maciej

85. Strzeszowski Szymon

86. Studziński Wojciech

87. Uwierzyski Wojciech

88. Widrowski Władysław

89. Wielorski Stanisław

90. Zaborowski Jakub

91. Zaborowski Wackaw

92. Zgłowicki Stanisław

93. Zieliński Władysław

94. Zieliński Wojciech

95. Zieliński Zygmunt

96. Żmijewski Szymon

97. Zukowski Walenty

\section{- Województwo podlaskie}

1. Bajkowski Paweł Stanisław

2. Bankowski Aleksander

3. Bankowski Mikołaj

4. Bielicki Stefan Malcher

5. Biernacki Aleksander

6. Biernacki Piotr Stanisław

7. Bloch Mateusz Marcjan

8. Broska Wojciech

9. Brzozowski Krzysztof

10. Brzozowski Lukasz

11. Ciecierski Stanisław

12. Czajkowski Maciej 
13. Dębiński Stanisław

14. Dulski Marcin

15. Dzierzek Adam

16. Godebski Bazyli

17. Gołyński Paweł

18. Grek Mikolaj

19. Gzowski Piotr

20. Hryniewicki Benedykt

21. Hryniewicki Filomon

22. Hryniewicki Jan

23. Hryniewicki Lew

24. Irzykowic Kasper

25. Iwanowski Przeclaw

26. Kajmir Wojciech

27. Karniewski Tomasz

28. Karp Stefan

29. Kącki Marcin

30. Klopotowski Hieronim

31. Kłopotowski Walenty

32. Kochański Jan

33. Kochański Piotr

34. Korowicki Maciej

35. Korzeniecki Olbrycht

36. Kosiński Baltazar

37. Kosiński Kasper

38. Kownacki Wojciech

39. Kotowicz Tomasz

40. Krasowski Andrzej Sobota

41. Krasowski Jakub

42. Krasowski Krzysztof

43. Kuczyński Adam

44. Kuczyński Mateusz

45. Kukawski Wojciech

46. Leżnicki Samuel

47. Lazowski Maciej

48. Lopiński Gabriel

49. Łoza Jakub

50. Luba Jan

51. Łyczko Erazmy

52. Lyczko Mikołaj

53. Lyczko Piotr

54. Makowiecki Aleksander

55. Malinowski Adam

56. Malinowski Jan Michał

57. Malinowski Seweryn

58. Mężeński Krzysztof

59. Mierzwiński Grzegorz

60. Mleczko Mieczysław

61. Moczalski Piotr

62. Mokrzycki Apollo
63. Morze Adam

64. Morze Andrzej

65. Nieciecki Szymon

66. Niedżwiedzki Maciej

67. Niemira Jan

68. Niemira Wojciech

69. Niewiarowski Stanisław

70. Niewiarowski Szczęsny

71. Nowosielski Stanisław

72. Orzeszko Jan

73. Orzeszko Jerzy

74. Orzeszko Marek Kazimierz

75. Wierzejski Albrycht Pieniążek

76. Pluciński Adam Aleksander

77. Pniewski Jakub

78. Pogorzelski Wojciech

79. Poniatowski Adam

80. Poniatowski Józef

81. Pudłochowski Stefan

82. Raczko Wojciech

83. Rozwadowski Jan

84. Rudnicki Jakub

85. Rudziński Piotr

86. Rytel Piotr

87. Rzewuski Albrycht

88. Rzewuski Jan

89. Saczko Malcher Julian

90. Sapieha Kazimierz

91. Siestrzewitowski Andrzej

92. Skaszewski Mikołaj

93. Skiwski Jan

94. Skiwski Stanisław

95. Skorupka Kazimierz

96. Skwierczyński Jan

97. Sokołowski Krzysztof

98. Stulewicki Jan

99. Szawłowski Aleksander

100. Szawłowski Szymon

101. Thołwiński Hieronim

102. Thołwiński Jan

103. Thołwiński Walerian

104. Trębicki Stanisław

105. Trzeszkowski Stanisław

106. Turski Kazimierz

107. Tuszewicki Jan

108. Tworkowski Stanisław

109. Warpechowski Jerzy

110. Warpęchowski Stefan

111. Warpecchowski Walenty

112. Warszycki Adam 
113. Warszycki Paweł

114. Wierzejski Wojciech

115. Wiszowaty Marcjan

116. Wodyński Andrzej

117. Wojno Piotr

118. Wojno Remian
119. Wyszyński Piotr

120. Zaleski Maciej

121. Zamoyski Jerzy

122. Zaszczyński Łukasz

123. Zdzarski Wojciech

124. Żolẹdowski Jan

\section{Ziemia rawska, województwo rawskie}

1. Błędowski Piotr

2. Blędowski Stanisław

3. Borkowski Marcin

4. Borsza Zachariasz

5. Brzostowski Baltazar

6. Brzostowski Stanisław

7. Bujalski Piotr

8. Chociwski Marcin

9. Chojnacki Adrian

10. Chojnacki Florian

11. Chojnacki Jan

12. Chojnacki Lukasz

13. Chojnacki Seweryn

14. Chojnacki Wojciech

15. Cielgowski Anzelm Grot

16. Dankowski Walerian

17. Domaniewski Jan

18. Głaczyński Stanisław Łuba

19. Głowiński Jan

20. Grabia Wojciech

21. Grochowski Daniel

22. Grochowski Marcin

23. Jarzyna Chryzostom

24. Jarzyna Jędrzej

25. Jarzyna Racibor

26. Kawiecki Stanisław

27. Kazimirski Stanisław

28. Kleniewski Jan

29. Konopiński Samuel

30. Krosnowski Jan

31. Krosnowski Pawel

32. Krosnowski Stefan
33. Kurzeski Jan

34. Luczycki Jan

35. Olszewski Stanislaw

36. Olszewski Szczęsny

37. Ołtarzowski Seweryn

38. Paradowski Jan Turczyn

39. Plichta Adam

40. Plichta Maksymilian

41. Poradowski Jedrzej

42. Radoński Andrzej

43. Rożnowski Grzegorz

44. Rudzki Michał

45. Rudzki Samson

46. Sadkowski Dobrogost

47. Sadkowski Hermolaus

48. Strzałkowski Stanisław

49. Sulgostowski Stanisław

50. Swidziński Wawrzyniec

51. Szaciński Tomasz

52. Swiejkowski Mateusz

53. Toszkowski Bartosz

54. Trzciński Jan

55. Trzciński Mikołaj

56. Trzciński Stefan

57. Wagrowski Daniel

58. Wolski Filip

59. Wolski Stefan

60. Wolski Szczęsny

61. Wohucki Bartosz

62. Załuski Spytek

63. Załuski Stanisław

64. Załuski Tomasz

- Ziemia sochaczewska, województwo rawskie
1. Bieniewski Benedykt
2. Bieniewski Stanisław
3. Boryszewski Kasper
4. Grzegorzewski Bartosz
5. Karnicki Stanisław
6. Kaski Hieronim
7. Kaski Jan

8. Kaski Sebastian

9. Lipski Jan

10. Łajszczewski Jan

11. Lajszczewski Szczęsny Zbożny

12. Mikołajowski Szczęsny

13. Okuń Aleksander

14. Okuń Maciej 
15. Osmolski Jakub

16. Rusiecki Jan

17. Stamirowski Hieronim Tomasz

18. Trzciński Maciej

19. Tułowski Andrzej
20. Tułowski Mikołaj

21. Wąsowski Bartosz

22. Wreecki Krzysztof

23. Zaboklicki Szymon

- Ziemia gostyńska, województwo rawskie

1. Bykowski Mateusz

2. Ciechomski Andrzej

3. Garnysz Jan

4. Garwaski Paweł

5. Garwaski Zygmunt

6. Gizycki Adam

7. Giżycki Jakub

8. Giżycki Remigiusz

9. Głogowski Samuel

10. Glogowski Zygmunt

11. Glogowski Zygmunt

12. Grabski Jakub

13. Grabski Krzysztof

14. Grabski Stanisław

15. Izbiński Adrian

16. Jastrzębski Jan

17. Jukowski Andrzej

18. Kawiecki Stanisław

19. Losowski Paweł

20. Małakowski Jakub

21. Maszyński Krzysztof

22. Modleski Maciej

23. Modleski Paweł

24. Niesałowski Stanisław

25. Piwo Krzysztof

26. Podczaski Pawel
27. Podczaski Stanisław

28. Podczaski Stanisław

29. Podczaski Stefan

30. Ruszkowski Marcin

31. Sierakowski Mikołaj

32. Sojecki Adam

33. Sojecki Jan

34. Stępowski Jakub

35. Stępowski Jan

36. Stępowski Marcin

37. Stępowski Sebastian

38. Strusiński Franciszek

39. Strusiński Stanisław

40. Szamowski Krzysztof

41. Smigielski Bernat

42. Tarnowski Jan

43. Wieszczycki Marcin

44. Wituski Maciej

45. Wituski Marcin

46. Wituski Władysław

47. Zaborowski Kasper

48. Zaborowski Wojciech

49. Zaciwilkowski Wawrzyniec

50. Zaleski Marek

51. Zborowski Marcjan

52. Zborowski Seweryn 